The Canadian Journal of Higher Education La revue canadienne d'enseignement supérieur

Volume XXXIII, No. 3, 2003 pages 71-114

\title{
Canadian Postsecondary Students With Disabilities: Where Are They? ${ }^{\text {' }}$
}

\section{CATHERINE S. FICHTEN, JENNISON V. ASUNCION, MARIA BARILE, CHANTAL ROBILLARD, MYRTIS E. FOSSEY \& DANIEL LAMB}

Dawson College, SMBD Jewish General Hospital, McGill University,

Concordia University, Université de Montréal

\section{ABSTRACT}

Results of a Canada-wide and a Quebec based study of students with a variety of disabilities in Canadian postsecondary education are presented. Study 1 involved 156 professionals. They represent $80 \%$ of the population of professionals who provide on-campus disability support services. Results indicate that (1) $8 \%$ of postsecondary institutions reported not having any students with disabilities, (2) overall, $2 \%$ of students are registered to receive disability related services from their postsecondary institutions, and (3) this varies from $1 / 2 \%$ to $6 \%$ across the country. Junior/community colleges had a higher percentage of students with disabilities registered to receive disability related services (3 3/4\%) than universities (1 2/3\%). (4) Distance education had 3\%. (5) Quebec has a smaller proportion of both college $(2 / 3 \%$ vs $6 \%$ ) and university $(1 / 2 \%$ vs $21 / 2 \%)$ students with disabilities than the rest of Canada. A targeted study involving 46 professionals who provide disability related services in Quebec's public junior/community colleges, the CEGEPs, revealed that lack of recognition of learning disabilities for postsecondary funding by the Quebec government is an important contributor to the small percentages, although it cannot explain the huge discrepancies 
between Quebec and the rest of Canada. Extrapolation suggests that there are over 100,000 students with disabilities currently enrolled in Canadian postsecondary education, although only $1 / 4$ to $1 / 2$ of them register to receive disability related services.

\section{RÉSUMÉ}

Les résultats d'une étude pancanadienne basée au Québec portant sur des étudiants ayant diverses incapacités dans des institutions postsecondaires canadiennes sont présentés. L'étude 1 impliquait 156 professionnels. Ils représentent $80 \%$ de la population des intervenants qui fournissent de l'appui, sur les campus, aux étudiants ayant des incapacités. Les résultats révèlent que (1) $8 \%$ des institutions postsecondaires rapportent qu'elles n'ont pas d'étudiants ayant des incapacités, (2) globalement, $2 \%$ des étudiants sont inscrits aux services offerts aux étudiants ayant des incapacités de leur institution postsecondaire, et (3) cette donnée varie de $1 / 2 \%$ à $6 \%$ à travers le pays. Les collèges communautaires ont un pourcentage plus élevé d'étudiants ayant des incapacités inscrits aux services d'appui (3 3/4\%) par rapport aux universités ( $12 / 3 \%$ ). (4) La formation à distance a $3 \%$ d'étudiants nécessitant des services de cette nature. (5) Le Québec a le pourcentage le plus faible au Canada d'étudiants ayant des incapacités aux niveaux collégial $(2 / 3 \%$ contre $6 \%)$ et universitaire $(1 / 2 \%$ contre $21 / 2 \%)$. Une étude cible impliquant 46 intervenants qui fournissent des services aux étudiants ayant des incapacités dans les collèges au Québec, les CEGEPs, révèle qu'un des facteurs contribuant aux faibles pourcentages est le fait que le gouvernement du Québec ne tient pas compte des difficultés d'apprentissage lors du financement. Cependant, ceci ne peut expliquer les différences énormes entre le Québec et le reste du Canada. Par extrapolation, il est possible d'avancer qu'il y a plus de 100000 étudiants ayant des incapacités présentement inscrits dans des institutions postsecondaires canadiennes, quoique seulement 25 à $50 \%$ de ceux-ci soient inscrits aux services offerts aux étudiants ayant des incapacités. 
Canada's junior/community colleges and universities provide education to well over a million Canadians (Statistics Canada, 1999a, 1999b). Postsecondary education has been targeted a key vehicle for providing a labour force ready to meet the challenges of the new workplace (Butlin, 1999). Indeed, the Government of Canada (2002) estimates that, "By 2004, more than $70 \%$ of all new jobs created in Canada will require some form of postsecondary education."

As we become increasingly reliant on the new knowledge based economy, citizens with disabilities can have an unprecedented opportunity to fully participate in the social and economic life of Canada. The knowledge based economy offers promising new possibilities for the close to $15 \%$ of Canadians over the age of 15 who have some level of disabilities (Statistics Canada, 2002a) in an environment where valuable commodities are no longer physical goods and services but information and knowledge (e.g., Loewen \& Tomassetti, 2002; Wolfe \& Gertler, 2001). This will only become a reality when they have the same opportunities for postsecondary education as other Canadians (e.g., Government of Canada, 1999; Pettigrew, 1998). The goal of the research presented here is to examine how well the need for postsecondary education for individuals with disabilities has been met in various parts of Canada.

It is only in the past two decades that North American institutions of higher education have begun to recognize the need to deliver disability related services to people with disabilities (Fichten, Bourdon, Creti, \& Martos, 1987; Hill, 1992; Leblanc, 1999). During this time, the number of people with disabilities in postsecondary education has increased dramatically, both in the U.S. and in Canada (e.g., Hill, 1996; Louis Harris \& Associates, 1994; Tousignant, 1995). "By 1998 more than half of adults with disabilities (51\%) had completed some college - a proportion almost identical to that for the nondisabled population" according to Louis Harris \& Associates (cited by the National Organization on Disability, 1999). In Canada, in 1996 a substantially smaller proportion of individuals with disabilities (33\%) than those without disabilities (49\%) had some postsecondary education (Human Resources Development Canada, 2002). Of Americans with disabilities, $12 \%$ graduated from university compared to $23 \%$ of the nondisabled population 
(Harris Interactive, 2000). In Canada, according to a recently released 2001 Census based report (Statistics Canada, 2003a), 11\% of Canadians with disabilities graduated from university. The comparable figure for nondisabled Canadians is $20 \%$, almost double the rate for Canadians with disabilities. The corresponding figures for college graduates are $16 \%$ versus $17 \%$, respectively.

Postsecondary education for individuals with disabilities, as it is for the rest of the Canadian population, is important because it helps fulfill personal goals, allows for effective competition in the job market and contributes to independence and financial security. At most North American postsecondary institutions there is at least one designated professional whose responsibility it is to provide disability related services and accommodations to students as well as to liaise and advocate with the campus community. Data from both the United States (Horn \& Berktold, 1999; Miller, 2001) and Canada (Jorgensen et al., 2002; Outcomes Group, 1998) show that postsecondary students with disabilities who receive adequate services persist in their studies and graduate at similar rates to their nondisabled peers.

University and college graduates with and without disabilities have better employment outcomes than people without postsecondary education (e.g., Government of Canada, 1996; Horn \& Berktold, 1999). Data on postsecondary students and graduates with disabilities indicate that most want to work (Hubka \& Killean, 1996). Thus, higher education is, if anything, even more important for people who have a disability. It has been shown, for example, that although employment of university graduates with disabilities is somewhat lower than that of their nondisabled peers both in the U.S. (e.g., Horn \& Berktold, 1999) and Canada (Fawcett, 1996), once employed, salaries are similar, and rates of employment are still substantially higher than that of students who did not complete university, who, in turn, fare better than those who never went to college (Canadian Council on Social Development, 2002; Government of Canada, 1996; Louis Harris \& Associates, 1994; Nichols, 1998). 


\section{Proportion of students with disabilities in North American postsecondary Institutions}

Data on the number of students with disabilities on campus are affected by the definition of disability used, what question is asked, of whom it is asked, and how percentages are calculated. Most research is based on self-reports by probability samples, although a substantial number are based on responses of on-campus professionals who provide disability related services. Estimates of the number of North American postsecondary students with some disability have ranged from 5\% to $11 \%$ (cf., American Association of Community Colleges, 1996; CADSPPE, 1999; Greene \& Zimbler, 1989; Henderson, 1999, 2001; Horn \& Berktold, 1999; Horn, Peter, \& Rooney, 2002; Hurst, \& Smerdon, 2000; National Center for Education Statistics, 2002). Generally, junior/community colleges have larger proportions of students with disabilities than universities (e.g., Most college students with disabilities attend community colleges, undated). For example, the 1995-96 National Postsecondary Aid Study (cited by Horn \& Berktold, 1999) indicates that approximately $6 \%$ of 21,000 American university undergraduates surveyed indicated that they had a disability. The 1994 freshman survey conducted by the Cooperative Institutional Research Program studied 237,777 students attending 461 American universities and 2 year colleges (Henderson, 1995). The 1998 freshman survey examined responses at 469 American junior/community colleges and universities. In both freshman surveys, approximately $9 \%$ of students reported at least one disability (Henderson, 1995, 1999). More recently, the freshman survey has looked only at university students. Here the data show that $6 \%$ of freshmen reported having a disability (Henderson, 2001). Large scale American results also show that between 1996 and 1998, 72\% of postsecondary educational institutions enrolled students with disabilities (Lewis, Farris \& Greene, 1999). Until the present investigation, comparable data for Canadian institutions did not exist. However, a recent survey shows that $6 \%$ of junior/community college graduates and $4 \%$ of university graduates in 1995 indicated that they had a disability (Taillon \& Paju, 2000). 


\section{Francophone students with disabilities in Quebec and the rest of Canada}

The situation of students with disabilities in Quebec is different from that of students in the rest of Canada in a variety of important ways. First, the language of instruction in the majority of postsecondary institutions is French. Second, in Québec, high school ends in grade 11. Students who plan on pursuing a university education must then complete a 2 year junior/community college (CEGEP) program of pre-university studies. This system is unique in Canada and Québec's 48 tuition free public CEGEPs account for close to 150,000 postsecondary students (Ministère de l'éducation, 2002). Moreover, there are many important differences between Québec's CEGEPs and junior/community colleges in the rest of Canada. In particular, there is the requirement in the CEGEPs that students take at least some academic literature and humanities courses, regardless of the nature of their program. Third, the conceptualization of disability is very different in Quebec from that of the rest of Canada (e.g., Fougeyrollas et al., 1998; Lemieux-Brassard, 2000).

There are francophone junior/community colleges and bilingual universities outside Québec. The circumstances of the students with disabilities enrolled in these institutions are likely to be different from both their anglophone and their Quebec based francophone peers.

\section{Present Investigation}

The goal of the two studies that comprise this investigation was to explore the representation of persons with disabilities in the Canadian postsecondary education system and to examine similarities and differences between anglophone and francophone universities and colleges. Study 1 focused on a cross-Canada comparison of students with disabilities in universities and junior/community colleges. Study 2 focused exclusively on Québec's unique junior/community college system, the CEGEPs. Three variables were evaluated: the number and percentage of students with disabilities at the respondent's campus/institution and the comparable number of nondisabled students. 


\section{METHOD}

\section{Study 1}

\section{Participants}

Participants were 156 on-campus professionals who provide services to students with various disabilities, including learning disabilities: 110 women and 46 men. They were participating in a larger investigation of the computer and adaptive technology needs of students with disabilities (Fichten et al., 2001). Ninety-six worked in a junior/community college, 58 in a university, and 2 in a postsecondary distance education institution ( 1 junior/community college and 1 university). Overall, participants worked for an average of 9 years providing services to students with disabilities (range $<1$ to 26 ).

Participants represent 91 of the 115 community/junior colleges and 55 of the 68 universities that were listed on the web pages of the ACCC or the AUCC on April 22, 2000. Interviewees met the following criteria: (1) their institution enrolled students, (2) they indicated that they currently enrolled students registered to receive disability related services, and (3) did not indicate that another postsecondary institution was looking after services for students with disabilities. Several institutions had 2 or more campuses which were not individual members of AUCC or ACCC but which had different individuals responsible for services to students with disabilities (e.g., some provinces have a regional college system with campuses in several cities). At several institutions, different individuals were responsible for services for students with specific impairments (e.g., learning disability versus other disabilities). In these cases we attempted to interview all these individuals. This resulted in more than one individual being interviewed at 10 postsecondary institutions. Thus the 156 participants represent 146 independent institutional members of the ACCC or the AUCC. The overall institutional participation rate was $80 \%$ : $79 \%$ participation from junior/community colleges, $81 \%$ from universities, and 2 of the 3 postsecondary distance education institutions. Additional details are available in Fichten et al. (2001). 


\section{Procedure}

To recruit participants we telephoned the 247 institutional members of the AUCC and the ACCC that were listed on their web sites on April 22,2000 . Whenever an institution was a member of both organizations, it was counted as a junior/community college rather than a university. This was done because most college and "university-college" members of AUCC did not have charters to grant their own degrees. Rather, they typically provided credits that could be transferred to a university. We asked to speak to the person responsible for providing services to students with disabilities. Of the 247 institutions/campuses listed, 46 were ineligible, mainly because their services for students with disabilities were delivered through another campus or institution. Three institutions had no students - they were merely administrative or research units. Fifteen had students, but none registered to receive disability related services. This left 183 eligible institutions.

Potential participants at the 183 eligible institutions were asked to volunteer. Despite repeated attempts to contact the individual responsible for providing services to students with disabilities we were unable to reach 11 institutions. 26 individuals contacted either refused to participate outright, mostly citing time constraints, or we were unable to make appointments due to problems with scheduling and unreturned phone calls. The remaining $156(86 \%)$ individuals were faxed or emailed the questions and an informed consent form prior to the scheduled appointment for the interview. To encourage candid responses, even if these did not reflect well on their educational institution, participants were assured that the information they provided would never be linked either to themselves or their institution.

Interviews were conducted by telephone during the spring of 2000 . Participants responded to structured interview questions related to the larger study in which they were participating (Fichten et al., 2001). In addition, they indicated the numbers of students with and without disabilities at their campus/institution by responding to the following questions, Approximately how many students with all types of disabilities, documented or not, including learning disabilities, are enrolled at your institution? and Approximately what is the total student enrollment at 
your institution? (This includes students with and without disabilities and refers to the same campus(es) as the previous question.) Respondents typically indicated that they could only provide the number of students with disabilities who were registered with them to receive disability related services. Participants noted that there are many students with disabilities who choose not to register to receive disability related services.

\section{Study 2}

\section{Participants}

Participants were 46 Quebec junior/community college (CEGEP) on-campus professionals who deliver services to students with disabilities ( 22 females and 24 males). They were participating in a larger investigation of the computer and adaptive technology needs of students with disabilities (Fichten et al., 2000). They represent 38 of the 43 public CEGEPs which enrolled students with disabilities, yielding an overall institutional participation rate of $88 \%$. Several CEGEPs had 2 or more autonomous campuses or units with different individuals responsible for services to students with disabilities. In this case, we attempted to interview everyone. Six participants were from anglophone and 40 from francophone CEGEPs. Approximately equal numbers of participants came from one of Québec's 3 large cities $(n=22 ; 48 \%)$ and from outlying regions $(\mathrm{n}=24 ; 52 \%)$. Respondents had worked providing services to students with disabilities for an average of 8 years $(\underline{\mathrm{SD}}=5$, range $=<1$ yr to $24 \mathrm{yr}$ ). Additional details are available in (Fichten et al., 2000).

It should be noted that there is substantial overlap between Studies 1 and 2: 20 of the 46 participants (43\%), 2 anglophone and 18 francophone individuals, are also part of the Study 1 sample. Nevertheless, more than doubling the sample size of Québec's colleges allowed for a more in depth analysis of differences within Québec, including examination of differences between anglophone and francophone CEGEPs.

\section{Procedure}

To recruit participants we telephoned the 97 individual campuses or sectors of the 48 public CEGEPs that were listed in the spring of 2000 on the web site of the Fédération des CEGEPs (2002); 8 of these were 
anglophone and 89 francophone. At this time we asked to speak to the person responsible for providing services to students with disabilities. Of the 48 CEGEPs, 5 indicated that currently there were no students registered to receive disability related services. Of the 97 campuses or sectors which comprise the 48 public CEGEPs, 12 did not enroll any students they were merely administrative or research units. Twenty-seven enrolled students, but had no students registered to receive disability related services. Potential participants at the remaining 58 campuses and sectors (i.e., those that did have students with disabilities) were asked to volunteer. $46(79 \%)$ participated and $12(21 \%)$ individuals contacted either refused to participate outright, mostly citing time constraints, or we were unable to make appointments due to problems with scheduling and unreturned phone calls. The same procedure as that in Study 1 was followed.

\section{RESULTS}

\section{Study 1}

\section{Students registered to receive disability related services in Canada's colleges and universities}

Fifteen of the 198 institutions on the AUCC or ACCC lists (7.58\%) indicated that although they had a student body, they currently enrolled no students registered to receive disability related services. The overall enrollment was $1,342,583$ at those institutions/campuses in our sample which had at least 1 student with a disability. The corresponding total number of students with disabilities was $33,503(2.50 \%)$. This indicates that since $7.58 \%$ of institutions did not enroll any students registered to receive disability related services, overall, less than $2.50 \%$ of the postsecondary enrollment in Canada is registered to receive disability services. Because our response rate was $80 \%$, extrapolating the scores suggests that there are approximately 41,879 students with disabilities registered to receive disability related services at Canadian postsecondary institutions.

An alternate method of computation yields a more optimistic percentage: $3.58 \%$. This involves calculating the percentage of students 
with disabilities at each institution and taking the mean. This optimistic percentage is due to the larger number of junior/community colleges in the sample. While smaller than universities, these generally have a larger proportion of students with disabilities. To ensure that comparable figures are used when comparing studies, it is important to ascertain which computational method is used.

There were great discrepancies among institutions (range: $<.01 \%$ to $35.64 \%, \underline{S D}=4.20 \%$, median $=2.21 \%$ ). Similarly, although average overall enrollment at participating postsecondary institutions was 8606, again there was great variability (range $=40$ to $45,000, \underline{\mathrm{SD}}=9559$ ). The same was true of the mean number of students with disabilities enrolled. While the mean was 215 , scores ranged from 1 to $1800(\underline{\mathrm{SD}}=262)$. To better understand the reasons for the large differences we examined variables related to enrollment of students with disabilities in a variety of ways.

Differences between colleges and universities. It can be seen in Table 1 that, in general, the mean overall enrollment of colleges $(\underline{M}=5648)$ was significantly lower than that of universities $(\underline{M}=13,455), \underline{t}(152)=5.30$, $\underline{p}<.001$. The total number of students with disabilities, however, was very similar $(\underline{\mathrm{M}}=211$ and $\underline{\mathrm{M}}=217$, respectively), $\underline{\mathrm{t}}(150)=.13, \underline{\mathrm{p}}>.05$. It is, therefore, not surprising that test results indicate that a significantly larger percentage of college $(\underline{M}=4.44 \%)$ students than university students $(\underline{M}=2.11 \%)$, have a disability $\underline{\mathrm{t}}(150)=4.10, \underline{\mathrm{p}}<.001$.

Differences among provinces and territories. Summary data on student enrollments broken down by province/territory and college/university status are available in Table 1 . Means and standard deviations show that, with the exception of 1 outlier score, the average percentage of students with disabilities registered to receive disability related services in Canada's provinces and territories ranges from $1.92 \%$ to $5.67 \%$ in all provinces. The outlier is Québec, where the percentage of students with disabilities is substantially lower: $0.55 \%$ (i.e., only $1 / 2$ of $1 \%$ ). A 1 -way ANOVA (10 Provinces) comparison indicates that there was a significant difference among the provinces in the proportion of students with disabilities, $\underline{E}(9,148)=4.27, \underline{p}<.001$. The Tukey HSD test shows that only 2 scores are significantly different $(p<.05)$ from each other. These show that Quebec enrolled a significantly lower percentage of 


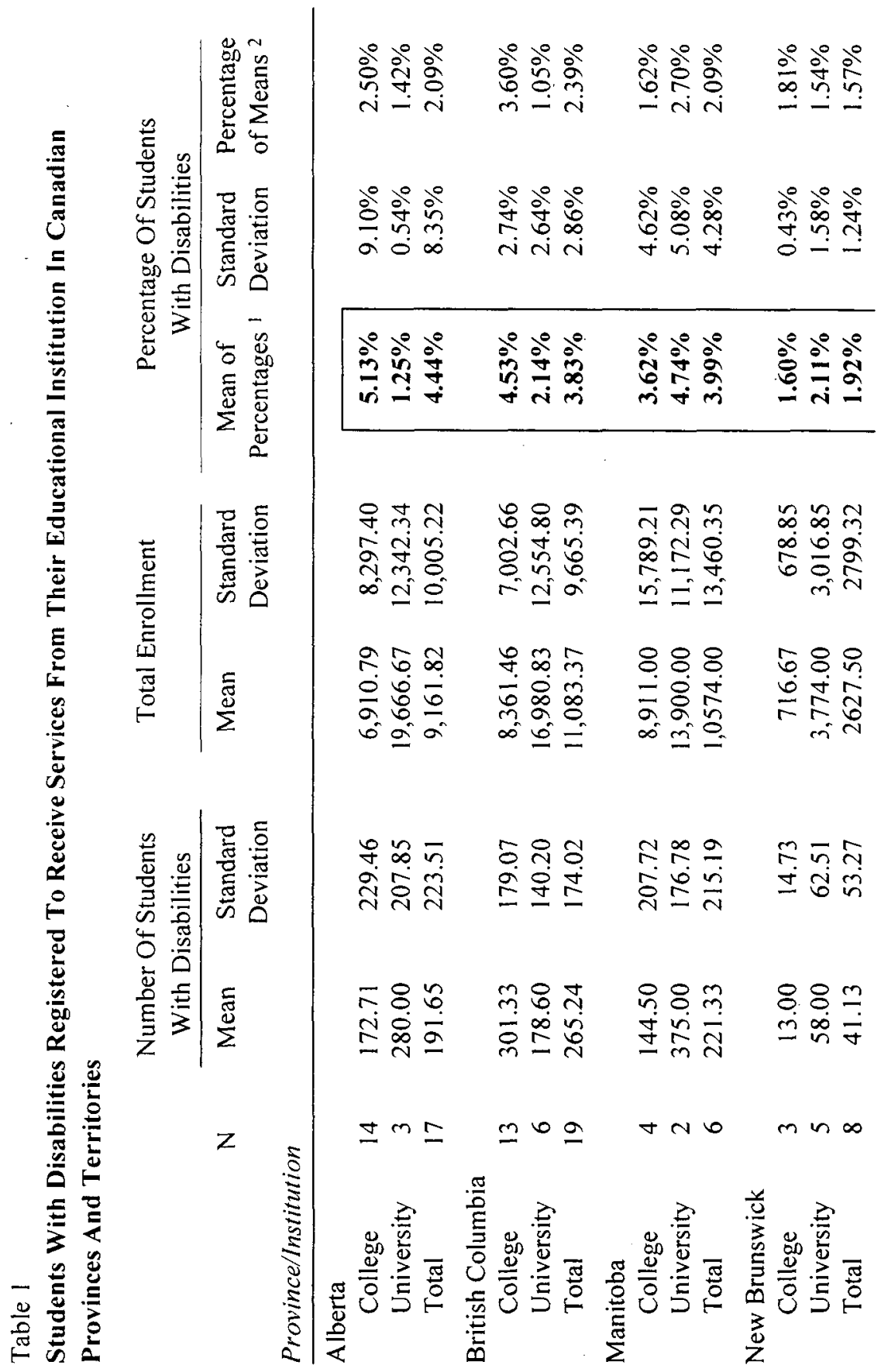

The Canadian Journal of Higher Education

Volume XXXIII, No. 3, 2003 


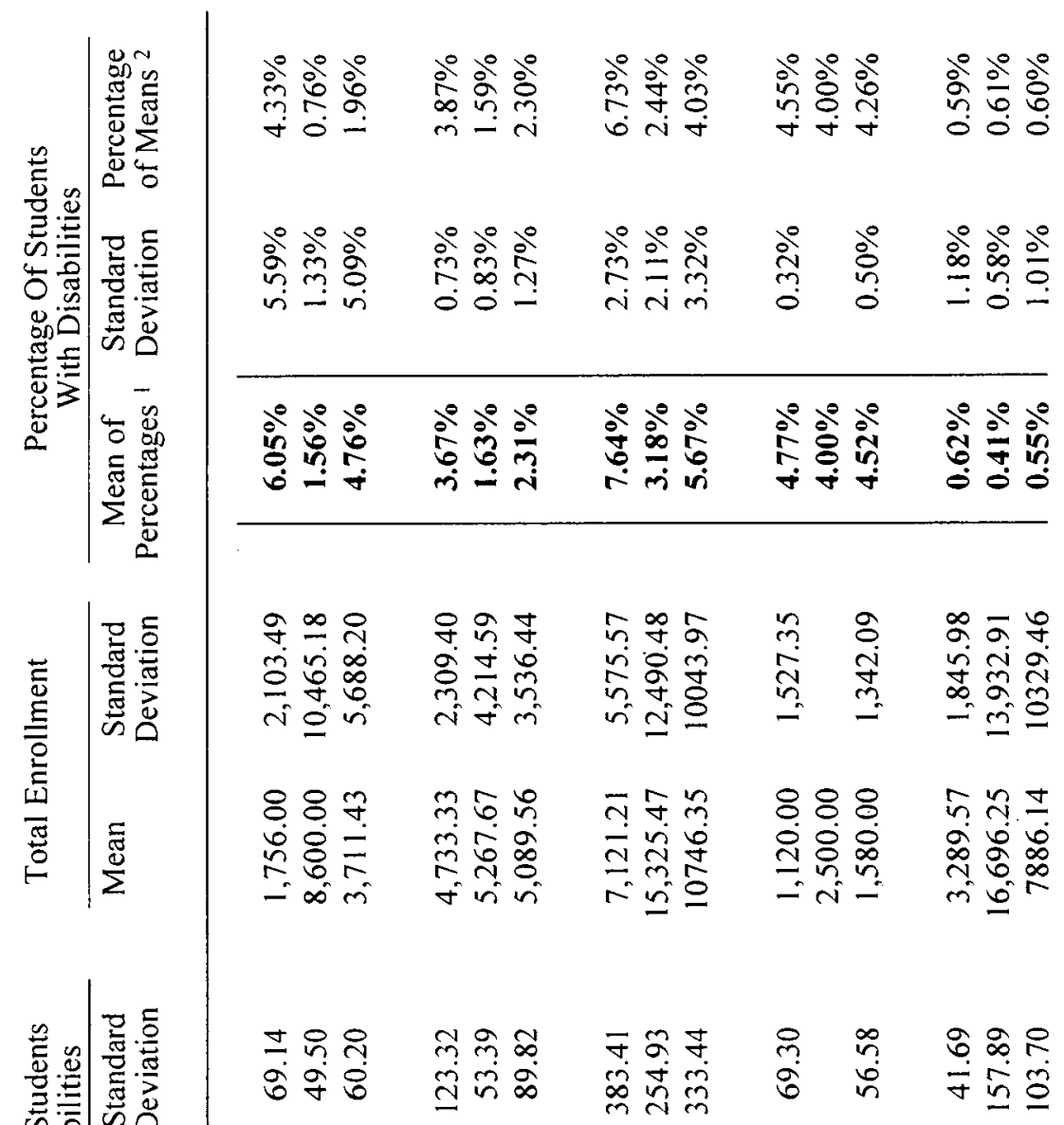

$88 \%$ m

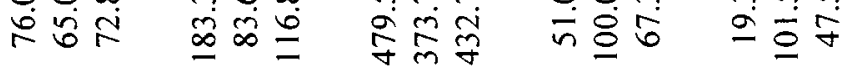

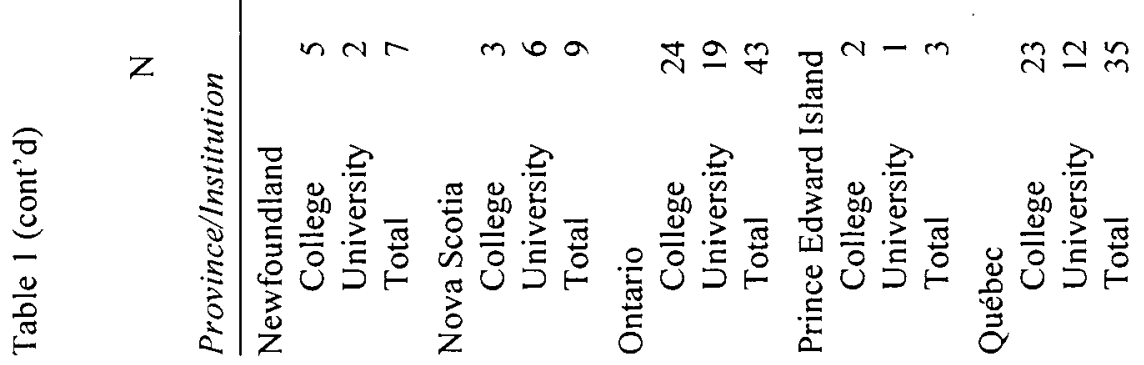


Total Enrollment

Number Of Students

With Disabilities

N Mean $\begin{gathered}\text { Standard } \\ \text { Deviation }\end{gathered}$

Province/Institution

Saskatchewan

College

University

Total

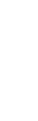

2

170.00

282.50

197.99

166.17

162.76

226.25

Territories (All)

College

Total

$3 \quad 35.33$

35.33

39.31

39.31

299.00

299.00

210.72

210.72

Distance Ed

2

Total $^{3}$

$\begin{array}{lrll}\text { College } & 96 & 211.41 & 287.18 \\ \text { University } & 58 & 217.35 & 219.49 \\ \text { Distance Ed } & 2 & 299.00 & 210.72 \\ \text { Total } & 156 & 214.75 & 262.10\end{array}$

$15,000.00$

Mean $\begin{gathered}\text { Standard } \\ \text { Deviation }\end{gathered}$

$13,825.00$

$4,242.64$

$10,465.30$

\subsection{7}

616.67

678.85

678.85

$$
\begin{array}{ll}
10,000.00 & 7,071.07 \\
10,000.00 & 7,071.07
\end{array}
$$

$\begin{array}{rr}5,647.74 & 6,541.98 \\ 13,455.17 & 11,727.88 \\ 10,000.00 & 7,071.07 \\ 8,606.30 & 9,559.18\end{array}$

\begin{tabular}{|c|c|c|}
\hline $5.62 \%$ & $6.19 \%$ & $1.34 \%$ \\
\hline $1.80 \%$ & $0.60 \%$ & $1.88 \%$ \\
\hline $3.71 \%$ & $4.22 \%$ & $1.64 \%$ \\
\hline $5.57 \%$ & $2.50 \%$ & $5.73 \%$ \\
\hline $5.57 \%$ & $2.50 \%$ & $5.73 \%$ \\
\hline $4.98 \%$ & $5.63 \%$ & $2.99 \%$ \\
\hline $4.98 \%$ & $5.63 \%$ & $2.99 \%$ \\
\hline $4.44 \%$ & $4.88 \%$ & $3.74 \%$ \\
\hline $2.11 \%$ & $2.03 \%$ & $1.62 \%$ \\
\hline $4.98 \%$ & $5.63 \%$ & $2.99 \%$ \\
\hline $3.58 \%$ & $4.20 \%$ & $2.50 \%$ \\
\hline
\end{tabular}

Percentage Of Students With Disabilities

\begin{tabular}{ccc}
\hline Mean of & $\begin{array}{c}\text { Standard } \\
\text { Percentage }\end{array}$ \\
Percentages & Deviation & of Means
\end{tabular}

${ }^{1}$ Scores are based on calculating the percentage of students with disabilities for each institution and taking the mean (i.e., each institution, regardless of its size, has an equal weight). Percentages are not identical to values obtained by dividing due to rounding errors.

2 Scores are based on dividing the average number of students with disabilities by the average overall enrollment in those schools. For example, the total enrollment reported by the 156 respondents was $1,342,583$. The total number of students with disabilities was $33,503(2.50 \%)$

3 Based on responses from 183 campuses/institutions. 15 additional campuses/institutions indicated they had no students with disabilities enrolled $(8 \%)$. 
students with disabilities than Ontario. None of the other provinces were significantly different from each other. To ascertain whether this difference was due to language or to differences in provincial policies we conducted a series of analyses on provincial and linguistic variables.

Colleges and universities in Quebec and the rest of Canada. First, we examined differences between institutions in Quebec and in provinces in the rest of Canada by conducting a series of 2-way ANOVA comparisons [2 Institution (College/University) $\times 2$ Location (Quebec/Rest of Canada)]. Dependent variables were: total enrollments, enrollments of students registered to receive disability related services, and percentage of students with disabilities. Of interest are main effects for location and interactions with the location variable. Results indicate that the average enrollment in postsecondary institutions in Quebec $(\underline{M}=7886)$ and the rest of Canada $(\underline{M}=8795)$ do not differ significantly. There was, however, a significant interaction of location and institution showing that, on average, Québec's colleges are relatively smaller and Québec's universities relatively larger than those in the rest of Canada, $\underline{F}(1,150)=4.13, \underline{p}<.05$.

The situation was somewhat different when enrollment of students with disabilities was considered. Here, the results show that the mean number of students with disabilities enrolled in postsecondary institutions is significantly lower in Quebec $(M=48)$ than in the rest of Canada $(\underline{M}=263), \underline{F}(1,148)=15.93, \underline{p}<.001$.

Perhaps the most compelling difference was found on the percentage of students with disabilities. Results indicate a significant main effect for location, $\underline{F}(1,148)=23.66, \underline{p}<.001$. In addition, the interaction effect approached significance, $\mathrm{F}(1,148)=3.80, \mathfrak{p}=.05$. These indicate that Quebec has a substantially smaller percentage of students with disabilities both at the college ( $\underline{\mathrm{M}}=0.62 \%$ vs $\underline{\mathrm{M}}=5.66 \%)$ as well as at the university levels $(\underline{M}=0.41 \%$ vs $\underline{M}=2.56 \%)$, with the difference being most pronounced among colleges.

Linguistic differences across Canada. Are the scores in Quebec related to linguistic differences or to differences in provincial policies and practices? To answer this question we conducted another series of ANOVAs, this time using language rather than location [2 Institution (College/University) $\times 2$ Language (Anglophone/Francophone)]. Of 
interest are main effects for language and interactions with the language variable. The results show that although none of the interactions were significant, there were significant main effects for language on both the number, $\mathrm{F}(1,147)=23.79, \underline{\mathrm{p}}<.001$, and the percentage of students with disabilities, $\underline{F}(1,147)=18.36, \underline{p}<.001$. Overall, the results are very similar to those on location, except that differences were generally somewhat smaller.

Because most of the francophone institutions are from Quebec ( $N=31$ vs $N=8$ outside Québec), the previous analysis was not a compelling test. Therefore, we conducted 3 series of comparisons examining the dependent variables in: francophone institutions in Quebec and elsewhere; anglophone institutions in Quebec and elsewhere; and anglophone and francophone institutions in Québec. We conducted separate evaluations for francophone colleges and for francophone universities in Quebec and the rest of Canada because the number of participating francophone universities outside Quebec $(\mathrm{N}=2)$ was too low for inferential statistical analysis.

In the case of francophone colleges inside and outside Quebec we performed a t-test. The significance test here is very stringent because of the sample sizes. The number of francophone colleges was 21 in Quebec but only 6 in the rest of Canada. Scores and test results in Table 2 show that while mean overall enrollment in francophone colleges in Quebec $(\underline{M}=3093)$ was significantly greater than in francophone colleges elsewhere in Canada $(\underline{M}=515), \underline{t}(25)=3.41, \underline{p}<.01$, the mean number of students with disabilities enrolled did not differ significantly $(\underline{M}=17$ and 23 , respectively), $\underline{\mathrm{t}}(25)=.32, \dot{\mathrm{p}}>.05$. The test on the percentage of students with disabilities in Quebec colleges, however, approached significance and showed that the mean percentage of students with disabilities was substantially lower in Quebec francophone colleges than in francophone colleges outside Quebec $(\underline{\mathrm{M}}=0.59 \%$ and $4.91 \%$, respectively $), \underline{\mathrm{t}}(25)=2.16, \underline{\mathrm{p}}<.10$.

It was not appropriate to conduct inferential statistical tests when evaluating francophone universities and anglophone colleges and universities inside and outside Quebec because of sample sizes. For example, there were data for only 2 francophone universities outside Quebec and for only 2 anglophone colleges and 2 anglophone universities inside 
Québec. Means and standard deviations for these comparisons are, however, available in Table 2.

In general, these show that on average, universities in Québec, both francophone and anglophone, have substantially greater overall enrollment than those in the rest of Canada. Anglophone colleges in Quebec and the rest of Canada are, however, similar in size. When it comes to the percentage of students with disabilities, however, regardless of language or college or university status, the proportion of students with disabilities in Quebec institutions was substantially lower. These relationships can best be seen in Figure 1, which compares anglophone and francophone colleges and universities inside and outside Quebec and illustrates the percentage of students with disabilities enrolled in a bilingual institution as well as in distance education. As Figure 1 clearly shows, both the province as well as the language are related to the percentage of students with disabilities, with both variables having an independent effect, and Quebec francophone institutions having the lowest proportions of students with disabilities.

\section{Is the size of the institution related to the percentage of students with disabilities?}

Because of substantial differences in total enrollments we wanted to find out whether institution size was related to the proportion of students with disabilities. To explore this possibility we correlated the percentage of students with disabilities with total enrollment for all institutions as well as for anglophone and francophone colleges and universities separately. Pearson product-moment correlations indicate a weak but significant negative relationship between overall enrollment and the percentage of students with disabilities, $\underline{\mathrm{r}}(152)=-.229, \underline{\mathrm{p}}<.01$. This indicates that the larger the institution, the smaller the percentage of students with disabilities. When this relationship was examined separately for colleges and universities, the coefficients show that the relationship was significant for anglophone institutions (colleges $\mathbb{r}(66)=-.263, "<.05$; universities $\underline{\mathrm{r}}(55)=-.274, \underline{\mathrm{p}}<.05)$. It was nonsignificant for francophone universities, $\underline{\mathrm{r}}(10)=.126, \underline{\mathrm{p}}>.10$. It only approached significance for francophone colleges, $\underline{\mathrm{r}}(25)=-.368, \underline{\mathrm{p}}<.10$. 


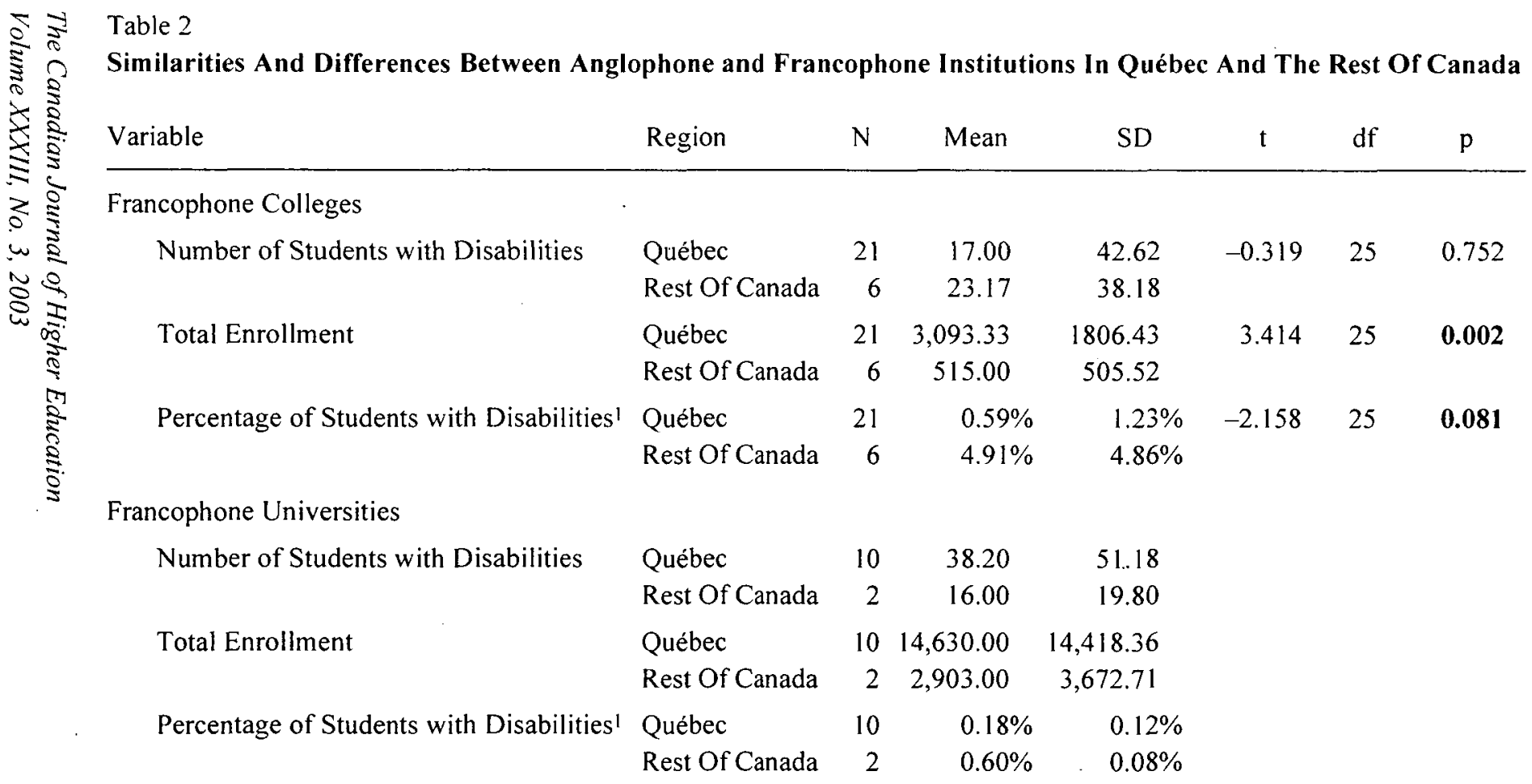


Table 2 (cont'd)

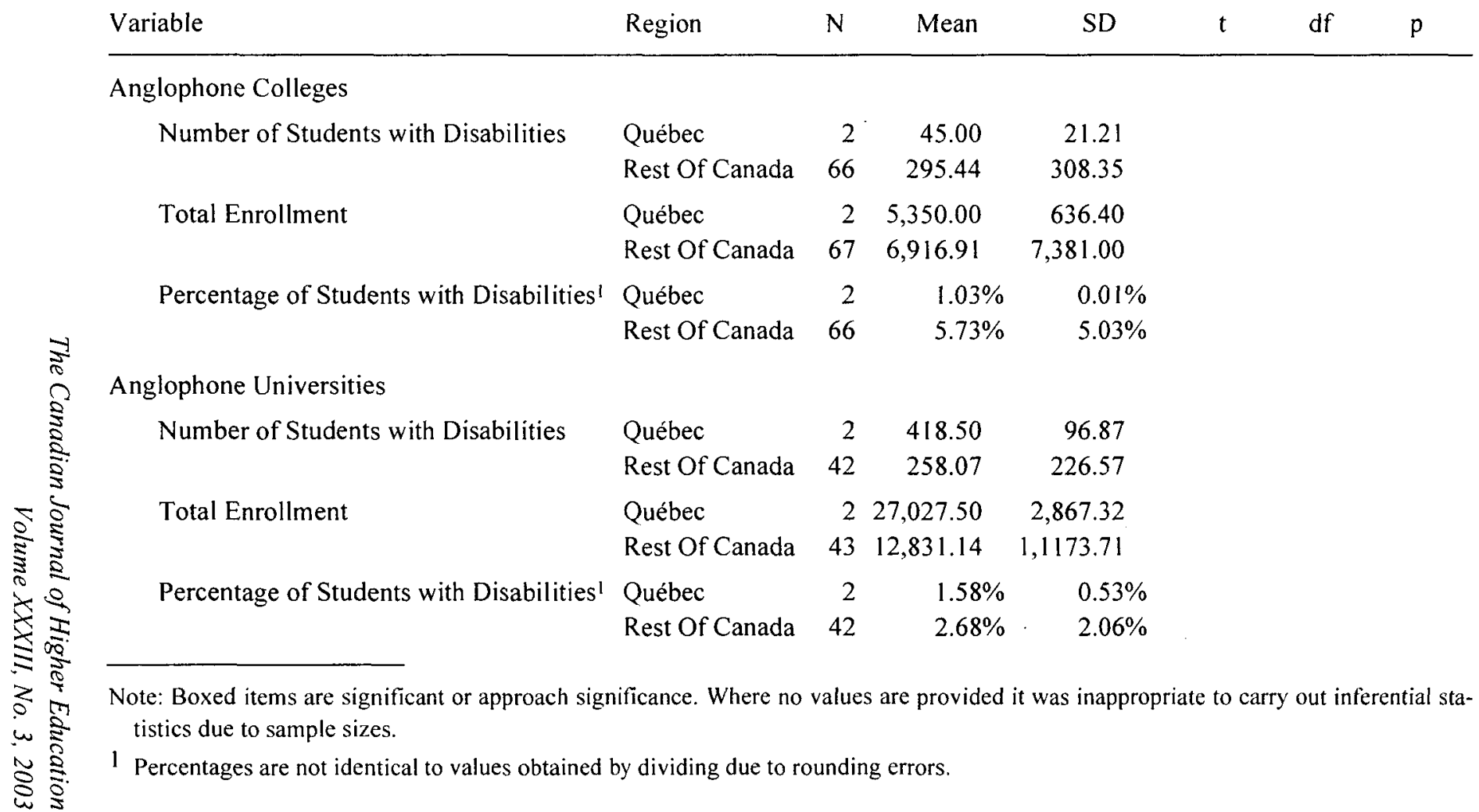




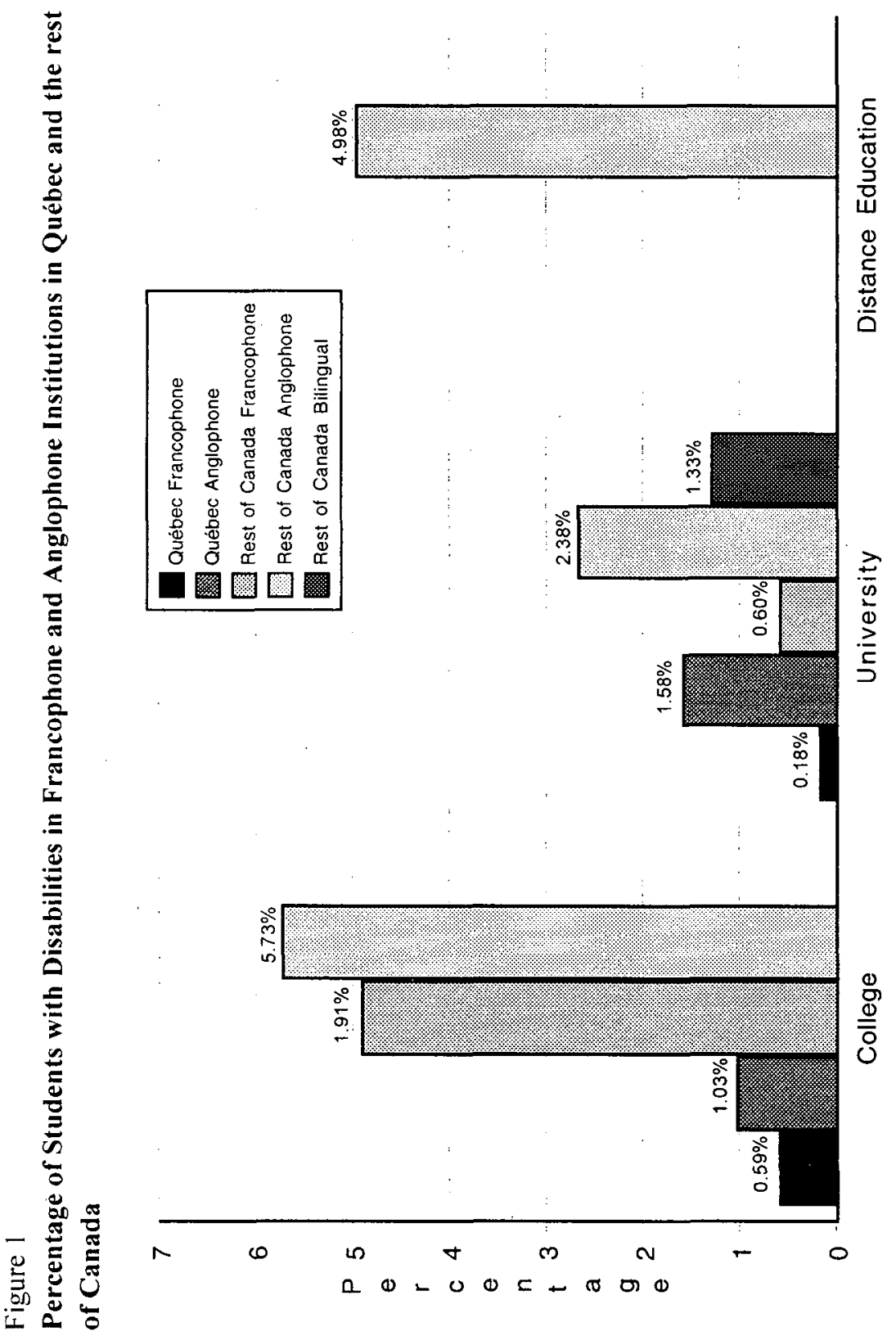

The Canadian Journal of Higher Education

Volume XXXIII, No. 3, 2003 


\section{DISCUSSION}

\section{Study 1}

The results show that there is a substantially and significantly smaller proportion of students with disabilities in Quebec colleges and universities than in institutions in the rest of Canada. Analyses which attempted to unconfound language and province were only partially successful in answering the question, "Is the difference due to language or to differences in provincial policies?" because of the limited number of anglophone institutions inside and the limited number of francophone institutions outside Québec. The closest approximation to an answer that we can propose is that most of the difference is due to provincial policies and practices (e.g., loss of social assistance benefits if the student enrolls for more than 6 hours of classes per week), with a smaller but independent role for language. To explore this issue further, in Study 2 we focused only on Québec's publicly funded junior/community college system, the 48 public CEGEPs (5 anglophone, 43 francophone). Because we were not restricted to members of ACCC, the sample sizes in Study 2 were considerably larger.

\section{Study 2}

\section{Students registered to receive disability related services in Québec's CEGEPs}

Because of the different ways in which disabilities are defined and as a check on participants' responses concerning total enrollments we used two sources of information: that provided by the participants and "official" data. This latter consisted of (1) total enrollment data for 1999 for each CEGEP from the Quebec Ministry of Education web page (Ministère de l'éducation, 2002) and (2) the number of students with disabilities enrolled in each CEGEP that was provided by the 3 designated "centres d'accueil." These 3 centers are responsible for administrative aspects of services for students with disabilities for all CEGEPs. The figures represent the number of students for whom an individualized education plan had been submitted and approved, and for whom services are 
"officially" provided by the CEGEPs and funded by the Ministère de l'éducation. Only data for the 38 CEGEPs which participants represented are used. Thus, it should be noted that scores for the 5 francophone CEGEPs which reported that they had no students with disabilities are excluded, as are data from the I anglophone and 4 francophone CEGEPs which did have students with disabilities but declined to participate.

Of the 48 public CEGEPs, $5(10.42 \%)$ indicated that they enrolled no students registered to receive disability related services. The data indicate that there are great discrepancies among CEGEPs in the percentage of students with disabilities (range $<.01 \%$ to $5.71 \%$ ). To better understand the reasons for this we examined variables related to the proportion of students with disabilities in a variety of ways.

Summary data on student enrolments at participants' institutions and percentages of students with disabilities based on the 2 data sources are available in Table 3. Overall, the findings show that the average total enrolment at the participating CEGEPs was approximately 3500 $(\underline{\mathrm{SD}}$ approximately $=2000$, range approximately $=725$ to 8,000 ). Information concerning the percentage of students with disabilities on campus shows that the mean was approximately $1 / 2$ of $1 \%$ (i.e., 5 per 1000 ).

Means in Table 3 and inferential statistical tests indicate no significant difference between official and participants' data on total enrollments. However, the 2 data sets differ significantly both on the number, $\underline{t}(35)=2.11, \mathfrak{p}<.05$, and the percentage of students with disabilities, $\underline{t}(35)=2.12, \underline{p}<.05$, with official scores being significantly lower than participants' scores.

A Pearson product-moment correlation indicates that the total enrollment figures provided by participants and the Ministry of Education web site are highly and significantly correlated, $\underline{r}(34)=.94, \underline{p}<.001$. To simplify presentation of the results, unless otherwise noted, total CEGEP enrollments provided by the participants are used in analyses. Correlation coefficients show that the number of students with disabilities provided by the 2 data sources are also highly and significantly correlated, $\underline{r}(35)=.688, \underline{p}<.001$. Given the very small numbers, it is not surprising that the coefficients are somewhat lower, although still highly significant, for the percentage of students with disabilities, $\underline{r}(35)=.453, \underline{p}<.01$. 
Table 3

Representation of Students with Disabilities in the CEGEPs: 2 Sources of Information

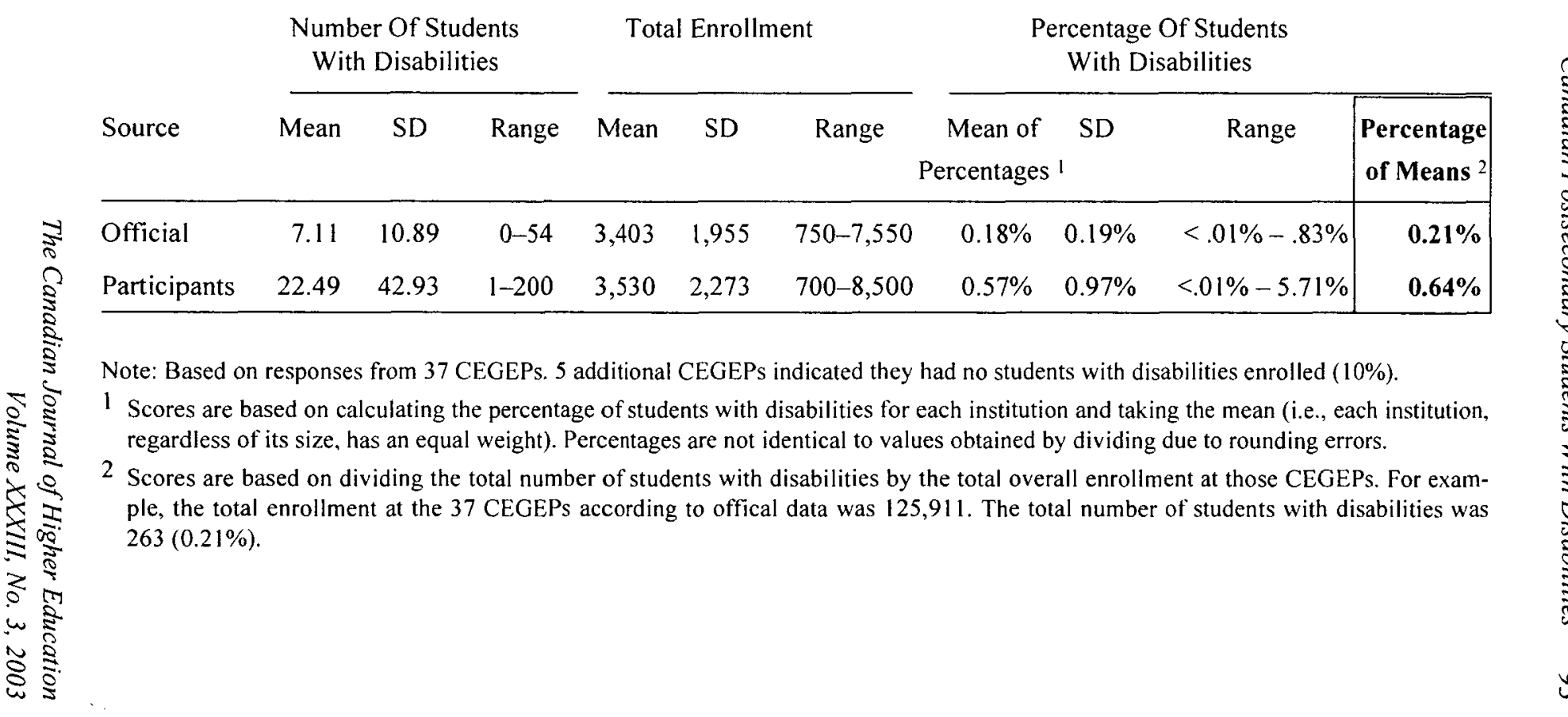


Is the size of the CEGEP related to the percentage of students with disabilities?

Because Study 1 showed that the correlation between the size of francophone colleges and the percentage of students with disabilities was not significant, the analysis was redone based on the larger number of Quebec francophone colleges (31) in the current sample. Anglophone CEGEPs were excluded from this analysis to avoid confounding language with institution size. Pearson product-moment correlation coefficients indicate no significant relationships between total enrollment and the percentage of students with disabilities $(31)=.097, \mathfrak{p}>.05$, corroborating the Study 1 findings.

\section{Is the language of the CEGEP related to the percentage of students with disabilities?}

It was also possible that francophone and anglophone institutions enrolled different percentages of students with disabilities. This is especially likely as students with learning disabilities, who typically make up approximately $1 / 3$ of North American institutions' populations of students with disabilities (Henderson, 2001; Hurst \& Smerdon, 2000; Most college students with disabilities attend community colleges, undated; Scott, 1997), are not officially recognized or funded in Québec. Indeed, among francophones, even the concept of a learning disability is frequently absent (e.g., Cardyn \& Bégin, 1998). To evaluate this possibility we examined scores for anglophone and francophone CEGEPs using both data sets. Because there are only 4 participating anglophone CEGEPs, statistical tests were not appropriate.

Total enrollments in anglophone CEGEPs (approximately 5,975) are substantially higher than in francophone CEGEPs (approximately 3,234), with anglophone colleges being almost twice the size of francophone colleges. Thus, it is not surprising that, as can be seen in Table 4, anglophone CEGEPs have more students with disabilities. What is surprising, however, is the magnitude of the difference, with anglophone CEGEPs having 4 to 8 times as many students with disabilities as francophone CEGEPs, and double the percentage of students with disabilities. 
To explore the differences further we carried out an additional series of tests to remove a source of confound. Learning disabilities may not be recognized as a disability in francophone CEGEPs. Therefore, we reduced the number of students with disabilities at anglophone CEGEPs by $1 / 3$, the approximate proportion of students with learning disabilities in most North American postsecondary educational institutions (cf., Horn \& Berktold, 1999). Because learning disabilities are not officially recognized for funding in either anglophone or francophone CEGEPs, this was done only for participant data. The impact of this can be seen in Table 4. This manipulation diminished the discrepancies somewhat. Nevertheless, the data indicate that there continue to be between 3 and 5 times as many students with disabilities in anglophone than in francophone CEGEPs. The percentages of students with disabilities reflect these findings. So the presence of learning disabilities in anglophone CEGEPS does not fully account for the discrepancy in the percentage of students with disabilities enrolled in anglophone and francophone CEGEPs.

\section{Location of CEGEPs}

Another possibility concerned the urban vs rural location of CEGEPs. Only one campus of one anglophone CEGEP is located in Québec's outlying regions, while more than half of the participating francophone CEGEPs are located there. Therefore, we examined similarities and differences between anglophone $(n=4)$ and francophone $(n=$ 14) city CEGEPs and between city and outlying regions francophone CEGEPs. Because there are only 4 anglophone CEGEPs in this data set, statistical tests were not made on city CEGEPs. In the case of francophone CEGEPs, however, a series of independent t-test were carried out based on the 2 data sets. Means and test results for these analyses are available in Table 5.

Francophone CEGEPs: City vs regions. Data in Table 5 and test results indicate that francophone CEGEPs in the cities have significantly higher total enrollments than francophone CEGEPs from the regions, $\underline{t}(31)=4.46, \underline{p}<.001$ (participants). There were also differences, although less substantial, in the number of students with disabilities, $\underline{\mathrm{t}}(31)=1.80, \underline{\mathrm{p}}<.10$, (participants), $\underline{\mathrm{t}}(31)=3.28, \underline{\mathrm{p}}<.01$, (official). When 
Table 4

Participants' Data: Differences Between Francophone and Anglophone CEGEPs

Variable

CEGEP

Mean

SD

All CEGEPs in the sample

Participants' scores

Total number of students

Anglophone

74

67

with disabilities

Francophone

16

35

$\%$ Students with disabilities 1

Anglophone

$1.09 \%$

$0.70 \%$

Francophone

$0.51 \%$

$0.87 \%$

Official scores

Total number of students

with disabilities

Anglophone

21

22

Francophone

5

8

$\%$ Students with disabilities 1

$\begin{array}{lll}\text { Anglophone } & 0.31 \% & 0.22 \% \\ \text { Francophone } & 0.16 \% & 0.18 \%\end{array}$

2 Controlling for learning disabilities in anglophone CEGEPs - participants' scores

Total number of students

with disabilities

$\%$ Students with disabilities 1
Anglophone

Francophone

Anglophone

Francophone
49

16 45

35

Note: Based on 4 anglophone and 33 francophone CEGEPs.

1 Percentages are not identical to values obtained by dividing due to rounding errors.

2 Learning disabilities may not be considered a disability in francophone CEGEPs.

Therefore, the number of students with disabilities at anglophone CEGEPs was reduced by $1 / 3$, the approximate proportion of students with learning disabilities in most North American postsecondary educational institutions. Because learning disabilities are not officially recognized for either anglophone or francophone CEGEPs, this was done only for participant data. 
Table 5

\section{Characteristics of Participating Anglophone and Francophone CEGEPs} from the Cities and the Outying Regions: 2 Sources Of Information

Data Source

\begin{tabular}{cc}
\multicolumn{2}{c}{ Anglophone } \\
Cegeps Cegeps \\
City
\end{tabular}

Francophone Francophone

Cegeps Cegeps

City Outlying Regions

Learning Sample

Participants' Data

Student Enrollment

$\begin{array}{lrrrr}\text { Mean } & \text { N/A } & 5,975 & 4,642 & 2,090 \\ \text { SD } & & (1,750) & (2,217) & (1,381) \\ \text { Number of CEGEPs } & 4 & 14 & 19\end{array}$

\# of Students with Disabilities

$\begin{array}{lrrrr}\text { Mean } & 49.24 & 73.50 & 28.64 & 7.00 \\ \text { SD } & & (67.30) & (53.06) & (6.90)\end{array}$

$\%$ of Students with Disabilities

$\begin{array}{lrrrr}\text { Mean } & .82 \% & 1.09 \% & .66 \% & .40 \% \\ \text { SD } & & (.0070) & (.0148) & (.0037)\end{array}$

Official Data

Number of CEGEPs

$4 \quad 14$

19

\# of Students with Disabilities

$\begin{array}{lrrrr}\text { Mean } & \text { N/A } & 21.00 & 9.79 & 2.11 \\ \text { SD } & & (22.02) & (10.33) & (2.42)\end{array}$

$\%$ of Students with Disabilities 1

\begin{tabular}{|c|c|c|c|c|}
\hline Mean & $\mathrm{N} / \mathrm{A}$ & $.31 \%$ & $.20 \%$ & $.13 \%$ \\
\hline SD & & $(.0022)$ & $(.0016)$ & $(.0019)$ \\
\hline
\end{tabular}

Note: Percentages do not equal scores obtained because of rounding errors.

1 Based on division by the total enrollment reported by participants.

2 Learning disabilities may not be considered a disability in francophone cegeps. Therefore, the number of students with disabilities at anglophone cegeps was reduced by $1 / 3$, the approximate proportion of students with learning disabilities in most North American postsecondary institutions. 
it came to the percentage of students with disabilities, however, although means in both data sets indicated a larger percentage of students with disabilities in city CEGEPs, the differences were not significant.

\section{City CEGEPs: Anglophone vs francophone}

Means in Table 5 indicate that anglophone and francophone city CEGEPs differ in a variety of ways. First, anglophone CEGEPs are approximately $25 \%$ larger than francophone CEGEPs. So it was not surprising that they also have substantially larger numbers of students with disabilities: approximately $21 / 2$ times more. But it is the percentage of students with disabilities that was also substantially greater in the anglophone CEGEPs, approximately $11 / 2$ times as many. It can be seen in Table 5 that controlling for learning disabilities in the anglophone CEGEPs by reducing the number of students with disabilities in the anglophone CEGEPs (participant data) does not alter the basic pattern of results.

\section{DISCUSSION}

\section{Limitations Of The Research}

The participation of a very large proportion of the population of individuals who provide disability related services to students was obtained in both studies. Thus, the sample is truly representative of the geographic, linguistic and institutional characteristics of the Canadian postsecondary educational system. Nevertheless, there are limitations that should be kept in mind when interpreting the findings.

A key concern relates to problems respondents had answering questions about the number of students on campus. This applies both to students with disabilities as well as overall campus enrollment and occurred because there are many different categories of students: full-time, day, evening, continuing education, etc. In general, the number of students with disabilities provided by respondents reflected the number registered to receive disability related services. It should be noted that this figure does not include students with disabilities who, for what ever reason, chose not to register to receive disability related services. 
In spite of these limitations, those validity indices which are available suggest that the responses in our study accurately reflect the reality of postsecondary students with disabilities. For example, in Study 2 (1) the overall enrolment data from official sources was highly correlated with data from participants, and (2) the findings using official sources for both the number and the percentage of students with disabilities on campus yielded similar results. In spite of these favorable checks on ecological validity, the limitations noted above need to be taken into consideration.

\section{ENROLLMENT}

\section{Students registered to receive disability related services in Canada's colleges and universities}

Our data indicate great discrepancies among the 156 institutions surveyed in the percentages of students with disabilities registered to receive services. The mean varied between $21 / 2 \%$ and $31 / 2 \%$, depending on the method of calculation $(21 / 2 \%$ of the Canadian postsecondary population and $31 / 2 \%$ when the "typical" institution is considered). The proportion of the Canadian postsecondary population registered to receive disability related services is, actually, somewhat lower than these values because institutions which enrolled students but had no students registered to receive disability related services are excluded from this calculation.

Proportions of students with disabilities at the various institutions ranged from close to $0 \%$ to more than $35 \%$. Eight percent of institutions had no students registered to receive disability related services. In most, however, the percentage of students with disabilities was under $1 \%$. In general, junior/community colleges had a higher percentage of students with disabilities $(41 / 2 \%)$ than universities $(2 \%)$. The actual mean number of students with disabilities at junior/community colleges and universities is similar, however ( 211 vs 217 , respectively). The difference in percentage is due to the larger size of Canadian universities.

When comparing the findings to those of American investigations it is important to note that this study examined only institutions which had at least 1 student with a disability, and that the data reflect the num- 
ber of students registered to receive disability related services from their institutions. Data about the number of students "known" to individuals who provide disability related services has been obtained in smaller scale Canadian and American studies. The findings from the present study are surprisingly similar to these. For example, the mean number of full time students with disabilities reported by the service providers in Killean and Hubka's (1999) Canadian study was 163 (range: $0-1200$ ). The overall full time enrollment for the same institutions was 7,507 (range: 200-50,000). Dividing the number of students with disabilities by the overall enrollment yields $21 / 4 \%$. American studies using similar methodologies also yield comparable percentages. For example, Lance's (1996) study of 87 campus based disability service providers showed a value of $21 / 4 \%$ as well (students with disabilities: $M=287$, range: $10-2100$; overall enrollment $M=13,361$, range: $100-60,000)$. Similarly, a very recent investigation by Jackson et al. (2001) showed a value of $22 / 3 \%$ (students with disabilities: $M=276$, overall enrollment $M=10,329$ ). The data from the present study, when the percentage is calculated in the same way, shows that $21 / 2 \%$ of students are registered to receive services from their postsecondary institution (students with disabilities: $M=215$, overall enrollment $M=8,606$ ).

These findings, as well as those of Canadians Killean and Hubka (1999), closely resemble those reported in the American Lance (1996) and Jackson et al. (2001) studies. Thus, the proportion of students with disabilities in American and Canadian postsecondary institutions appear to be similar. As noted earlier, large scale epidemiological self-report surveys show that the percentage of students with disabilities in American postsecondary institutions varies somewhere between $5 \%$ and $11 \%$. Individuals who provide disability related services to students with disabilities typically report only $2 \%$ to $3 \%$. Therefore, it seems safe to say that between $1 / 2$ and $3 / 4$ of students with disabilities do not register with their office for students with disabilities either in Canada or the United States. Based on 1998-1999 enrollments in Canadian postsecondary education (Statistics Canada, 2001a, 2001b) we estimate that there are well over 100,000 students with disabilities currently enrolled in Canadian postsecondary education, although only between 1/4 and 1/2 
of them are registered to receive disability related services.

\section{Canada's provinces and territories.}

The data show the average percentage of postsecondary students with disabilities registered to receive disability related services varies from $1 / 2 \%$ to $6 \%$ in Canada's provinces and territories. Ontario, Prince Edward Island, and the Territories have the largest proportion of postsecondary students with disabilities and Québec, New Brunswick, and Saskatchewan have the lowest. Ontario has the largest percentage of junior/community college students $(72 / 3 \%)$ and Manitoba has the largest proportion of university students (43/4\%). Quebec has the smallest proportion of students with disabilities both at the college $(2 / 3 \%)$ and university levels $(1 / 2 \%)$, with the difference being greatest in colleges.

Linguistic differences. Our results show that there is a substantially and significantly smaller proportion of students with disabilities in Quebec colleges (2/3\% vs $53 / 4 \%$ ) and universities (1/2\% vs $21 / 2 \%$ ) than in comparable institutions in the rest of Canada. Across Canada, smaller proportions of francophone than anglophone postsecondary students are registered to receive disability related services from their postsecondary institution, although Quebec francophone colleges have a smaller proportion of students with disabilities than francophone colleges outside Quebec (2/3\% vs 5\%). Similarly, in Québec, francophone colleges have substantially smaller percentages of students with disabilities than anglophone colleges (2/3\% vs $1 \%)$. Québec's anglophone (1 $1 / 2 \%$ ) universities have larger proportions of students with disabilities than francophone (1/4\%) universities. Regardless of language or college or university status, the proportion of students with disabilities in Quebec institutions is substantially lower. Analyses which attempted to unconfound language and province were only partially successful in answering the question, "Is the difference due to language or to differences in provincial policies?" The closest approximation to an answer than we can propose is that most of the difference is due to provincial policies and practices, with a smaller but independent role for language. The low enrollment of students with disabilities in Quebec postsec- 
ondary institutions has been lamented by a variety of sources (e.g., Allie \& Hébert, 1998; AQEHPS, 1999; OPHQ, 1995).

\section{Why does Quebec have a lower proportion of students with disabili- ties that the rest of Canada?}

To explain the huge discrepancies between Quebec and the rest of Canada the study examined - and rejected - five hypotheses related to demographic factors and the nature of postsecondary education in Quebec and the rest of Canada. The sixth hypothesis provides a partial explanation of the results.

Hypothesis 1. Québec's colleges are more "academic" than those in the rest of Canada (i.e., Québec's 2 year "pre-university" college programs are the equivalent of the first year of university in most other provinces and the 3 year "career" programs contain substantial academic content). In addition, attending a college in the rest of Canada is generally based on a choice between university or college. In Quebec most students must first attend college if they wish to go to university. Although all of these differences are generally true, both our current data set as well as our previous results (Fichten, Barile, \& Asuncion, 1999) show that the discrepancies between Quebec and the rest of Canada holds true for universities as well. Moreover, in Study 1 we categorized "university colleges" outside Quebec as colleges, even though many of these offer courses that are accepted for credit in university degree programs. Recent census data (Statistics Canada, 2003a) also indicates a substantial gap between Québec and Canada in the number of junior / community college graduates with disabilities $(11 \%$ vs $16 \%$, respectively). Thus, the "academic" orientation of Quebec colleges does not account for the low numbers.

Hypothesis 2. Quebec does not value education for its citizens the way other provinces do. This, hypothesis, too, was rejected because, if anything, Quebec is slightly ahead of the rest of Canada in stressing education for its population. For example, according to Statistics Canada (2000a), in 1999 Quebec accounted for 24\% of Canada's population. Yet, in 1996-97 Quebec accounted for $32 \%$ of full and part time college students (Statistics Canada, 2000b), and $28 \%$ of full and part time university students 
(Statistics Canada, 2000c). Similarly, of individuals aged 17 to 34, the rate of participation in postsecondary education in Quebec is $20 \%$, compared to the Canadian average of $17 \%$ (Lefebvre, 2000).

Hypothesis 3. Individuals responsible for providing services to college students with disabilities in the large colleges typical of provinces other than Quebec may have more sophisticated accounting systems for keeping records on students with disabilities and a more comprehensive view of what constitutes a disability. With this comes a more formalized approach to registering and recognizing students with disabilities on campus. This hypothesis, too, was rejected. Although Québec's junior/community colleges are likely to be smaller than their counterparts in other provinces, the opposite is true of Québec's universities. Yet, the percentage of students with disabilities is substantially lower in Quebec universities as well.

Hypothesis 4. The population of persons with disabilities in Quebec is lower than the rest of Canada; therefore the discrepancy in student enrollments simply reflects the distribution in the general population. In 1991 the percentage of persons with disabilities over the age of 15 in Quebec was slightly lower (14\%) than in the rest of Canada (18\%) (Statistics Canada, 2000d, 2000e, 2000f). In 2001, the difference is larger (10\% vs 15\%) (Statistics Canada, 2002b). However, it should be noted that the 2001 survey includes learning disabilities, which $21 / 4 \%$ of Canadians over the age of 15 reported. A much lower rate than this was reported in Quebec. For example, in Ontario 197,360 individuals reported having a learning disability. In Quebec, only 80,140 did so. In spite of differences in population parameters, the magnitude of the difference is not comparable to the difference found for postsecondary students.

Hypothesis 5. The differences are due to linguistic variables. As noted by others, there are numerous differences in the postsecondary education of Quebec anglophones and francophones (cf. Butlin, 1999; Norris, 1999). Our findings indicate that language is an important variable in the Quebec context as well (i.e., there is a larger proportion of students with disabilities in Québec's anglophone (approximately 1\%) than francophone junior/community colleges (approximately 1/2\%) as well as universities ( $1 / 4 \%$ vs $11 / 2 \%$, respectively). The same is true, but 
to a much lesser extent, in the rest of Canada (college: francophone $\underline{M}=5 \%$ vs anglophone $\underline{M}=53 / 4 \%$; university: francophone $\underline{M}=1 / 2 \%$ vs anglophone $\underline{M}=23 / 4 \%$ ). Nevertheless, neither anglophone nor francophone colleges or universities in Quebec approach their counterparts in the rest of Canada. This leads us to conclude that it is not primarily language that is the determining factor, but, rather, some other systemic differences in the ways of conceptualizing and dealing with individuals with disabilities in Quebec and the rest of Canada (cf., Fougeyrollas et al., 1998; Lemieux-Brassard, 2000).

Hypothesis 6. Differences are due to the nature of the disabilities that are officially "recognized" in Quebec and in the other Canadian provinces. Students with learning disabilities, who typically make up about $1 / 3$ of North American institutions' populations of students with disabilities (e.g., Fichten et al., in press; Jackson et al., 2001; Roessler \& Kirk, 1998; Scott, 1997), are not recognized as having a disability for funding purposes in Québec. Among francophones, in particular, learning disability as a clinical entity is virtually nonexistent (Cardyn \& Bégin, 1998). Thus, Quebec enrollments, especially in francophone institutions, exclude most of the $1 / 3$ of postsecondary students with disabilities who probably have a learning disability. To evaluate this possibility, in Study 2 we conducted a series of comparisons where we controlled for learning disabilities by subtracting $1 / 3$ of the students with disabilities in Québec's anglophone colleges. While this mitigated the differences between Quebec anglophone and francophone colleges somewhat, the correction by no means eliminated the very large discrepancies. Moreover, in the current investigation participants from anglophone colleges and universities in Quebec indicated that they had large numbers of students with learning disabilities who received disability related services such as tutoring, extra time for exams, etc. Nevertheless, the difference between anglophone colleges and universities in Quebec and their counterparts outside Quebec continue to show very substantial differences that are considerably greater than that which can be reasonably accounted for by students with a learning disability. So while this hypothesis has some merit, it fails to completely account for the magnitude of the difference between Quebec and the rest of Canada. 
Frankly, the reasons for the large linguistic differences within Quebec or the large differences between Quebec and the rest of Canada are difficult to understand, as neither institution size, nor institution location are related significantly to the percentage of francophone students with disabilities in francophone institutions. Indeed, no significant correlations with the percentage of students with disabilities were found on any of the variables examined. However, the poor educational representation of persons with disabilities in Quebec is also reflected in (1) the proportion of individuals with disabilities who failed to complete high school in Quebec and in the rest of Canada (i.e., $44 \%$ vs 34\%, respectively when rates for nondisabled individuals are virtually identical at 25\%) (Statistics Canada, 2003a), (2) employment (Canadian Spinal Cord Association, 2000; Statistics Canada, 2001, 2003a), and (3) income (Statistics Canada, 2003a). This suggests that systemic, fundamental differences in how individuals with disabilities are dealt with need to be explored. In particular, the situation of students with disabilities in Québec's elementary and high schools need further investigation as does transition programming from high school to both higher education and employment.

The challenge for policy and research is to ensure that qualified Canadians with all types of disabilities have access to postsecondary education to the same extent as individuals without disabilities. It is only by doing so that the promise of the knowledge based economy for citizens with disabilities can be realized. In future research, analysis of recruitment, advertising, and admissions practices of postsecondary institutions and of policies and strategies in high schools relating to students with disabilities should be considered. These can greatly impact the number of students with disabilities registered. 


\section{References}

American Association of Community Colleges (AACC). (1996). Disability support services - National survey. Available November 6, 1998 from http://www.aacc.nche.edu/spcproj/dissrvcs/survey.htm

AQEHPS (Association Québécoise des Étudiants Handicapés au Postsecondaire). (1999, January). Les étudiants ayant des incapacités, un regard statistique. Montreal, QC: Author.

Butlin, G. (1999). Determinants of postsecondary participation. Education Quarterly Review, 5(3), 9-35. Statistics Canada Cat. No. 81-003.

CADSPPE/ACCSEHP. (1999). Towards developing professional standards of service: A report on support for students with disabilities in postsecondary education in Canada. Retrieved October 9, 1999 from http://www.cadsppe. cacuss.ca/english/CADSPPE-Standards/CADSPPE-Standards.html

Canadian Council on Social Development (CCSD). (2002). CCSD's disability information sheet. Number 4. Available December 1, 2002 from http://www.ccsd.ca/drip/research/dis4/index.htm

Canadian Spinal Cord Association. (2000). Workforce participation Survey of Canadians with spinal cord injuries - Final report. Retrieved December 1, 2002 from http://www.canparaplegic.org/national/level2.tpl?varl=story \&var2=113.00

Cardyn, B., \& Bégin, C. (1998). Troubles d'apprentissage: Rapport final. Montréal, QC: Université du Québec à Montréal.

Fawcett, G. (1996). Living with disability in Canada: An economic portrait. Hull, QC: Human Resources Development Canada, Office for Disability Issues.

Fédération des CEGEPs. (2002). Établissements d'enseignement collégial. Retrieved December 9, 2002 from http://www.meq.gouv.qc.ca/ens-sup/enscoll/Etablis-coll/Etablissements.asp

Fichten, C.S., Asuncion, J.V., \& Barile, M. with the collaboration of: Robillard, C., Fossey, M.E., Judd, D., Guimont, J.P., Tam, R., \& Lamb, D. \& Partner Representatives: Généreux, C., Juhel, J.C., Senécal, J., \& Wolforth, J. (2001). Computer and information technologies: Resources for the postsecondary education of students with disabilities. Final Report to the Office of Learning Technologies. Hull, QC: Office of Learning Technologies. Resources in Education and ERIC Document Reproduction Service (ED 458733 and EC 308 679). Retrieved October 1, 2001 from http://adaptech. dawsoncollege.qc.ca/pubs/olt01pdf.exe Abstracted in EDUCAUSE (ID Number CSD1700). 
Fichten, C.S., Asuncion, J.V., Barile, M., Fossey, M.E., Robillard, C., Judd, D., Wolforth, J., Senécal, J., Généreux, C., Guimont, J.P., Lamb, D., \& Juhel, JC. (in press). Access to information and instructional technologies in higher education I: Disability service providers' perspective. Journal of Postsecondary Education and Disability.

Fichten, C.S., Barile, M., \& Asuncion, J.V. (1999). Learning technologies: Students with disabilities in postsecondary education. Final report to the Office of Learning Technologies. Ottawa, ON: Human Resources Development Canada. Eric Document Reproduction Service (ED 433625 EC 37369). Retrieved December 9, 2002 from http://adaptech.dawsoncollege.gc.ca/ pubs/79160final e.pdf

Fichten, C.S., Barile, M., Robillard, C., Fossey, M., Asuncion, J., Généreux, C., Judd, D., \& Guimont, J.P. (2000). Access to college for all: ITAC Project - Computer and adaptive computer technologies in the CEGEPs for students with disabilities. Final report to PAREA (Programme d'aide à la recherche sur l'enseignement et l'apprentissage), July, 2000. Québec, QC: Ministère de l'Éducation. Eric Document Reproduction Service (ED445457). Retrieved July, 2000 from http://www.adaptech.dawsoncollege.qc.ca/ pubs/itacallpdf.exe

Fichten, C.S., Bourdon, C.V., Creti, L., \& Martos, J.G. (1987a). Facilitation of teaching and learning: What professors, students with a physical disability and institutions of higher education can do. Natcon, 14, 45-69.

Fougeyrollas, P., Cloutier, R., Bergeron, H., Cote, J., \& St. Michel, G. (1998). The Quebec classification: Disability creation process. Available address: International Network on the Disability Creation Process. P.O. Box 225, Lac St. Charles, Quebec G3G 3C1. Available email: pfougeyrollas@irdpq.qc.ca

Government of Canada. (1996). Equal citizenship for Canadians with disabilities: The will to act: Federal Task Force on disability issues. Ottawa, ON: Minister of Public Works and Government Services, Canada.

Government of Canada. (1999). Future directions. Ottawa, ON, Hull, QC: Human Resources Development Canada. Catalogue number MP80-2/1 1-1999E. Retrieved November 30, 2002 from http://www.statcan.ca/english/Pgdb/ imdb/sddseduc02a.htm

Government of Canada. (2002). Knowledge matters: Skills and learning for

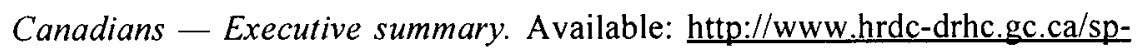
ps/sl-ca/doc/summary.shtml 
Greene B., \& Zimbler, L. (1989). Profile of handicapped students in postsecondary education, 1986: National postsecondary aid study survey report. Washington DC: Superintendent of documents, U.S. Government Printing office.

Harris Interactive Inc. (2000). 2000 N.O.D./Harris survey of Americans with disabilities. New York, NY: Harris Interactive.

Henderson, C. (1995). College freshmen with disabilities: A triennial statistical profile, 1995. Washington, DC: HEATH Resource Center.

Henderson, C. (1999). College freshmen with disabilities: A biennial statistical profile (Statistical Year 1998). Washington, DC: HEATH Resource Center. Retrieved April 13, 2001 from http://www.acenet.edu/bookstore/ pdf/CollegeFresh.pdf

Henderson, C. (2001). College freshmen with disabilities: A biennial statistical profile (Statistical Year 2000). Washington, DC: HEATH Resource Center. Retrieved November 12, 2002 from http://www.heath.gwu.edu/PDFs/ collegefreshmen.pdf

Hill, J.L. (1996). Speaking out: perceptions of students with disabilities at Canadian universities regarding institutional policies. Journal of Postsecondary Education and Disability, 11(1), 1-13.

Hill, J.L. (1992). Accessibility: Students with disabilities in universities in Canada. Canadian Journal of Higher Education, 22(1), 48-83.

Horn, L., \& Berktold, J. (1999). Students with disabilities in postsecondary education: a profile of preparation, participation and outcomes. (NCES 1999-187). Washington, DC: U.S. Department of Education - National Center for Education Statistics.

Horn, L., Peter, K., \& Rooney, K. (2002). Profile of undergraduates in U.S. postsecondary institutions: 1999-2000. Statistical analysis report. (NCES 2002 -168). Washington, DC: U.S. Department of Education - National Center for Education Statistics. Retrieved December 10, 2002 from http://nces.ed.gov/ pubs2002/2002168.PDF

Hubka, D., \& Killean, E. (1996). Employment opportunities for postsecondary students and graduates with disabilities: A national study. Ottawa, ON: National Educational Association of Disabled Students.

Hubka, D., \& Killean, E. (1999). Working towards a coordinated national approach to services, accommodations and policies for postsecondary students with disabilities: Ensuring access to higher education and career training. Ottawa, ON: National Educational Association of Disabled Students. 
Human Resources Development Canada. (2002). Advancing the inclusion of persons with disabilities. A Government of Canada Report (Cat. No.: RH374/1-2002E). Ottawa, ON: Authors. Retrieved March 31, 2003, from http://www.hrdc-drhc.gc.ca/hrib/sdd-dds/odi/documents/pdfs/fdr.pdf

Hurst, D., \& Smerdon, B. (2000). Postsecondary students with disabilities: Enrollment, services, and persistence (Stats in Brief). Students with disabilities in postsecondary education: a profile of preparation, participation and outcomes. Washington, DC: U.S. Department of Education - National Center for Education Statistics.

Jackson, K., Morabito, S.M., Prezant, F.P., \& Michaels, C.A. (2001). The current status of technology on campus for students with disabilities: The DSS perspective. Presentation at the Annual AHEAD (Association on Higher Education And Disability) Conference, Portland, Oregon.

Jorgensen, S., Fichten, C.S., Havel, A., Lamb, D., James, C., \& Barile, M. (in press). Students with disabilities at Dawson College: Success and outcomes - Final Report Presented to PAREA. 2003. Montréal, QC: Adaptech Research Network, Dawson College. Retrieved October 5, 2003 from http://adaptech. dawsoncollege.qc.ca/pubs/PAREA_2k3.pdf Eric Document Reproduction Service.

Killean, E., \& Hubka, D. (1999). Working towards a coordinated national approach to services, accommodations and policies for post-secondary students with disabilities: Ensuring access to higher education and career training. Report to the National Educational Association of Disabled Students. Ottawa, ON: NEADS. Available address: 426 Unicentre, Carleton University, Ottawa, ON, K1S 5B6.

Lance, G.D. (1996). Computer access in higher education: A national survey of service providers for students with disabilities. Journal of College Student Development, 37(3), 279-288.

Leblanc, A. (1999). Integration of students with disabilities in the CEGEP network of Quebec: A historical overview and case study. M.Ed. thesis, Faculty of Education, Université de Sherbrooke, Sherbrooke, QC.

Lefebvre, F. (2000). Taux de scolarisation de la population - Le Québec au rang des pays les plus avancés. Available from http://www.meq.gouv.qc.ca/ CPRESS/cprss2000/c000317.htm 
Lemieux-Brassard, L. (2000). Another step toward independent living: Montreal independent living resource centre (ILRC) feasibility study. Report prepared for the Canadian Association of Independent Living Centres. A vailable June 15, 2000 via e-mail: Deborah Kennard, Co-chairperson, Montreal ILRC Feasibility Study, d.kennard@videotron.ca

Lewis, L., Farris, E., \& Greene, B. (1999). An institutional perspective on students with disabilities in postsecondary education. National Center for Education Statistics: Statistical Analysis Report. Retrieved August 17, 2001 from http://nces.ed.gov/pubs99/1999046.pdf U.S. Department of Education Office of Educational Research and Improvement. NCES 1999-046.

Loewen, G., \& Tomassetti, V. (2002). Fostering independence through refreshable Braille. Presentation at the Developing Skills for the New Economy: International Conference on Technical and Vocational Education and Training, Manitoba. Abstracted at http://www.umanitoba.ca/unevoc/ 2002conference/text/wp loewen.shtml

Louis Harris \& Associates. (1994). N.O.D./Harris survey of Americans with disabilities. New York, NY: Louis Harris \& Associates.

Miller, E.F. (2001). Supporting students with disabilities to achieve success in higher education. Presentation at the Annual AHEAD (Association on Higher Education And Disability) Conference, Portland, Oregon.

Ministère de l'éducation - Enseignement supérieur (Gouvernement du Québec). (2002). Nombre d'élèves inscrits au collégial à l'enseignement ordinaire et à temps plein, selon le type de formation et la classe : réseau public. Retrieved December 8, 2002 from http://www.meq.gouv.qc.ca/stat/Sipeec/ Reseau public.htm

Most college students with disabilities attend community colleges. (undated). EDINFO Number 3 from the ERIC Clearinghouse for Community Colleges. Retrieved November 30, 2002 from http://www.gseis.ucla.edu/ERIC/ edinfos/EDINFO3.HTML

National Center for Education Statistics. (2002). Disabled students in postsecondary education (1995-96). Digest of Education Statistics, Table 212. Retrieved November 20, 2002 from http://nces.ed.gov/pubs2002/digest2001/ tables/dt212.asp

National Organization on Disability (1999). Education and disability. Disability Agenda: A Quarterly Publication of the National Organization on Disability, 3(4). 
Nichols, F. (1998). L'après-CEGEP: Insertion professionnelle. Taux d'activité et de chômage en fonction des études post-secondaires et des incapacités. Presentation at Rencontre de notre 10e année de rencontre avec les répondants. CEGEP Vieux Montréal, Montréal, QC.

Norris, A. (1999, May 29). Anglo = English speaker? The Gazette, p. A13.

Office des personnes handicapées du Québec. (1995). États généraux sur l'éducation - Mémoire. Drummondville: Office des personnes handicapées du Québec. Abstract available June 13, 2000 from http://www.ophq.gouv.qc.ca/ Position/D Etatsmem.htm

Outcomes Group. (1998). 1998 outcomes of former students with disabilities: $B C$ college and insistitute student outcomes report. Available Nov 26, 2002 from http://outcomes.ceiss.org/Publications/collegereports/ 1999 Services.pdf

Pettigrew, P.S. (1998, Nov.). Notes for remarks by the Honourable Pierre S. Pettigrew of Human Resources Development Canada to the National Educational Association of Disabled Students. Presentation at the National Educational Association of Disabled Students (NEADS) Biannual Conference, Ottawa, ON, Canada

Roessler, R.T., \& Kirk, H.M.. (1998). Improving technology training services in postsecondary education: Perspectives of recent college graduates with disabilities. Journal of Postsecondary Education and Disability, l3(3), 48-59.

Scott, S. (1997). Accommodating college students with learning disabilities: How much is enough? Innovative Higher Education, 22(22). Retrieved August 17, 2001 from http://www.coe.uga.edu/ldcenter/ r accommodations.html

Statistics Canada. (1999a). Institutions, enrolments and teachers, 1996-97 to 1998-99 - Table 1. Education Quarterly Review, 5(3), 56-57. Statistics Canada Catalogue no. 81-003.

Statistics Canada. (1999b). Canadian statistics: Education: Enrolment. Retrieved August 11, 1999 from http://www.statcan.ca/english/Pgdb/ People/educat.htm

Statistics Canada. (2000a). Population by age group (1999). Retrieved June 22, 2000 from http://www.statcan.ca/english/Pgdb/People/Population/ demo31b.htm

Statistics Canada. (2000b). Community college postsecondary enrollment (1993-1997 both sexes). Retrieved June 22, 2000 from http://www.statcan.cal english/Pgdb/People/Education/educ02a.htm 
Statistics Canada. (2000c). University enrolment, full-time and part-time, by sex (1993-1997 both sexes). Retrieved June 22, 2000 from http://www. statcan.ca/english/Pgdb/People/Education/educ03a.htm

Statistics Canada. (2000d). Population aged 15 and over with a disability, by nature of disability (Newfoundland, Prince Edward Island, Nova Scotia, New Brunswick - Census 1991). Retrieved June 24, 2000 from http://www. statcan.ca/english/Pgdb/People/Health/health $12 \mathrm{a}$.htm

Statistics Canada. (2000e). Population aged 15 and over with a disability, by nature of disability (Québec, Ontario, Manitoba, Saskatchewan - Census 1991). Retrieved June 24, 2000 from http://www.statcan.ca/english/Pgdb/ People/Health/health $12 \mathrm{~b}$.htm

Statistics Canada. (2000f). Population aged 15 and over with a disability, by nature of disability (Alberta, British Columbia, Yukon, Northwest Territories - Census 1991). Retrieved June 24, 2000 from http://www.statcan.ca/english/ Pgdb/People/Health/health $12 \mathrm{c}$. htm

Statistics Canada. (2001, June). Canadian Centre for Justice statistics profile series: Canadians with disabilities. Catalogue No. 85F0033MIE. [Internet]. Available December 1, 2002 from http://www.statcan.ca/english/ freepub/85F0033MIE/free.htm

Statistics Canada. (2001a). Community college postsecondary enrollment (1998-1999). Retrieved August 24, 2001 from http://www.statcan.ca/english/ Pgdb/People/Education/educ02a.htm

Statistics Canada. $(200 \mathrm{lb})$. University enrollment, full-time and part-time, by sex (1998-1999). Retrieved August 24, 2001 from http://www.statcan.ca/ english/Pgdb/People/Education/educ03a.htm

Statistics Canada. (2002a). A profile of disability in Canada, 2001: Participation and Activity Limitation Survey (PALS). Catalogue no. 89-577XIE. Available Dec 3, 2002 from http://www.statcan.ca/english/freepub/89577-XIE/89-577-XIE01001.pdf

Statistics Canada. (2002b). A profile of disability in Canada, 2001 Tables. Catalogue no. 89-579-XIE. Available Dec 3, 2002 from http://www. statcan.ca/english/freepub/89-579-XIE/89-579-XIE02001.pdf

Statistics Canada. (2003a). Participation and Activity Limitation Survey, 2001: Education, employment and income of adults with and without disabilities - Tables. (Catalogue no. 89-587-XIE). Retrieved Oct. 5, 2003, from http://www.statcan.ca/english/freepub/89-587-XIE/pdf/89-587. XIE03001.pdf 
Taillon, J., \& Paju, M. (2000). The class of '95: Report of the 1997 national survey of 1995 graduates. Human Resources Development Canada. Hull, QC. Catalogue No. SP-137-04-99. [Internet]. Retrieved August 17, 2001 from http://www.hrdc-drhc.gc.ca/stratpol/arb/publications/books/class95/class95.pdf

Tousignant, J. (1995). La vie étudiante des personnes handicapées dans les etablissements d'enseignement universitaire Québécois (un bilan des années 1989 a 1995). Québec, QC: Ministère de l'éducation: Direction générale des affaires universitaires et scientific.

Wolfe, D.A., \& Gertler, M.S. (2001). The new economy: An overview. Report for the Social Sciences and Humanities Research Council of Canada Toronto, ON: Munk Centre for International Studies.

\section{Notes}

1 Acknowledgements: This research was executed in partnership with the Canadian Association of Disability Service Providers in Postsecondary Education (CADSPPE), the Service d'aide à l'intégration des élèves (SAIDE-CEGEP du Vieux Montréal), le Services aux étudiants handicapés du CEGEP de Sainte-Foy, the Association québécoise des étudiants ayant des incapacités au postsecondaire (AQEIPS), and the National Educational Association of Disabled Students (NEADS). Funding for the research was provided by grants from the Office of Learning Technologies (OLT), the Social Sciences and Humanities Research Council of Canada (SSHRC), FCAR, and Dawson College. We are grateful for their assistance and support. Special thanks go to our very active Advisory Board and the Adaptech online community for feedback, constructive criticism, and guidance. We are especially grateful to Jane Drover (Mount Allison University), Alice Havel (Dawson College), and Frank Smith (NEADS). We also wish to thank all those who participated in the research as well as the dedicated members of our research team: Ray Tam, and Jason Lavers from Dawson College; Crystal James and Rachel Fima from Concordia University; Rhonda Amsel from McGill University; and Jocelyne Côté from Marionoplois College for their substantial contribution to this research. 